\title{
THE IMPACT OF SHOPPING CENTERS IN RURAL AREAS AND SMALL TOWNS IN THE OUTER METROPOLITAN ZONE (THE EXAMPLE OF THE SILESIAN VOIVODESHIP)
}

\author{
Krystian Heffner ${ }^{1}$, Małgorzata Twardzik ${ }^{2}$
}

Received 22 January 2015; Accepted 12 June 2015

\begin{abstract}
Shopping centers in the Silesian Voivodeship have a significant impact on smaller settlement units located in outer areas of agglomerations. It consists mainly in changes related to social, economic, as well as functional and spatial spheres. Studies shows that shopping centers take over more and more functions of higher order (services, public culture, administration) and restrict the economic activity in rural areas outer areas of agglomerations. At the stage of the irrepressible process of suburbanisation of rural areas surrounding large urban agglomerations and structural changes in towns, it is difficult to conclusively assess the consequences of the operation of shopping centers in outer metropolitan areas. The impact of shopping centers on small towns and rural areas is a very dynamic process and requires systematic research.
\end{abstract}

Key words: modern trade, shopping centres/malls, rural areas, outer areas of agglomerations, spatial processes.

Streszczenie: Doświadczenia wielu państw wskazują, że w zewnętrznych strefach metropolii zachodzą trwałe zmiany, nie tylko związane z postępującą urbanizacją, ale również spowodowane powstaniem i funkcjonowaniem centrów handlowych. Ich rozwój w charakterystycznych lokalizacjach w przestrzeni miejskiej, szczególnie w obszarach zewnętrznych dużych miast skutkuje licznymi zmianami. Klasyczne teorie lokalizacji handlu i usług nie uwzględniają specyfiki nowoczesnych centrów handlowych oraz warunków ich funkcjonowania w przestrzeni. Rozpoznanie wpływu centrów handlowych zlokalizowanych w zewnętrznych strefach metropolii na rozwój jej otoczenia jest ważnym uzupełnieniem $w$ teorie rozwoju lokalnego i regionalnego, które traktują handel (m.in. centra handlowe) jako jeden z czynników zewnętrznych, nie doceniając jego bezpośredniego wpływu na procesy rozwojowe. Przeprowadzone badania miały na celu rozpoznanie następstw w sferze przestrzennej, funkcjonalnej i społeczno-ekonomicznej w otoczeniu dużych miast wywołanych przez centra handlowe. Przedmiotem badania były obszary zewnętrzne aglomeracji miejskich w województwie śląskim. Zwrócono uwagę na oddziaływanie

\footnotetext{
1 Prof. zw. dr hab. Krystian Heffner, Department of Spatial Economics, University of Economics in Katowice, ul. 1 maja 50, 40-287 Katowice, Poland; e-mail: krystian.heffner@ue.katowice.pl

${ }^{2}$ Dr. Małgorzata Twardzik, Department of Spatial Economics, University of Economics in Katowice, ul. 1 maja 50, 40287 Katowice, Poland; e-mail: malgosia-twardzik@wp.pl
} 
centrów handlowych na małe miasta i obszary wiejskie położone w zewnętrznej strefie aglomeracji górnośląskiej oraz w strefach wpływu Bielska-Białej, Rybnika i Częstochowy. Rozpoznanie następstw funkcjonowania centrów handlowych w wybranych zewnętrznych strefach metropolii (na terenach wiejskich oraz małych miastach) może wpłynąć na weryfikację polityki władz lokalnych w zakresie gospodarowania przestrzenią oraz kształtowania struktury funkcjonalnej na jej obszarze.

Słowa kluczowe: nowoczesny handel, centra handlowe, obszary wiejskie, obszary aglomeracji zwenętrznej, procesy przestrzenne

\section{Introduction}

Modern trade, especially shopping centers ${ }^{3}$ (malls) have become an inseparable element of modern agglomerations and large cities in Poland. They derive from the tradition of former town marketplaces, round which trade was developed and the life of local community flew. Similarly to them, modern shopping malls are becoming important centres of social life, serving for commercial, entertainment, recreational, cultural, educational, integration as well as socialising purposes.

Shopping malls in the Silesian Voivodeship have a significant impact on smaller settlement units located in outer areas of agglomerations. It consists mainly in changes related to social, economic, as well as functional and spatial spheres. Research conducted (2013) directly among residents, entrepreneurs and local authorities made it possible to identify consequences of the functioning of shopping malls in the region. Studies shows that shopping malls take over more and more functions of higher order (services, public culture, administration) and restrict the economic activity in rural areas outer areas of agglomerations.

At the stage of the irrepressible process of suburbanisation of rural areas surrounding large urban agglomerations and structural changes in towns, it is difficult to conclusively assess the consequences of the operation of shopping malls in outer economic areas. The impact of shopping malls on small towns and rural areas located in the outer economic area is, in terms of time and form, a very dynamic process and requires further systematic research.

In Poland, there are over 430 malls (2014). The local government has a significant influence on location of shopping malls through the forming of local plans developed spatial. The part of the decision can have arbitrary character.

The aim of the paper was to identify the changes in small towns and rural areas under the influence of the modern trade, especially shopping centres in outer areas of agglomeration in the Silesia Region. The aim of the research ${ }^{4}$ was to identify the impact of shopping malls on the spatial, functional and socio-economic field in the vicinity of large cities. The research was devoted to outer areas of urban agglomerations in the Silesian Voivodeship. Many studies highlight that it is a significant research and practical problem (Amcoff et al. 2011, p. 129; Leeuwen, Rietveld, 2011, p. 1107; Lukić, Jakovčić, 2004, pp. 39-54; Powe, Shaw 2004, p. 405; Sić 2007, pp. 5-15).

Attention was paid to the impact of shopping malls on small towns and rural areas located in the outer area of Upper Silesian Agglomeration and in the sphere of influence of Bielsko-Biała, Rybnik and Częstochowa. The result of the implementation of the project is an identification of consequences of the functioning of shopping malls in outer metropolitan areas as well as their

\footnotetext{
${ }^{3}$ A shopping mall (shopping centre) is a modern collection of stores, catering establishments and service providers, including at least a couple of shops and a catering establishment serving basic meals, run by different companies. It constitutes a whole in terms of trade, assortment and services, construction and architecture, organisation and administration, and is adapted to serve motorised purchasers (see: Lambert 2006, Heffner, Twardzik 2013, Teller 2008]

${ }^{4}$ Research conducted in March 2014 directly among residents (600), entrepreneurs (200) and local authorities (14) made it possible to identify consequences of the functioning of shopping malls in the Silesian Voivodeship, and to verify initial hypotheses. The type of research - direct interview
} 
assessment from the perspective of their impact on spatial planning, economy, local communities and development of rural areas.

The project was focused on the verification of the following research hypotheses:

- Shopping malls located in outer metropolitan areas result in more negative than positive boosts to the development.

- Shopping malls located in outer metropolitan areas significantly change the functional structure of these territories.

- The way in which a shopping mall influences rural areas depends on its type and specific context of its location in space.

Identification of consequences of the operation of shopping malls in chosen outer metropolitan areas (in rural areas and in small towns) can impact the verification of the policy adopted by local authorities in relation to spatial planning and forming the functional structure of the space. It will result in more conscious (rational) decisions in terms of localising new shopping malls, which will reduce the number of local conflicts related to the location of such facilities.

\section{Development of shopping malls in Poland}

Until the 1990s, mainly small, traditional shops operated in Poland. Individual, large-area department stores and supermarkets localised in the largest cities were not characterised by features of shopping centre. First shopping malls were established at the end of the 1990s and those were mainly facilities of first and second generation ${ }^{5}$. They were located primarily on the outskirts of cities or away from them, and they were suitable for customers with cars. In subsequent years, next generations of centres developed in Poland, in new locations, with new assortment and a range of additional functions ${ }^{6}$.

Their development implied changes in the size, structure of tenants, architectural form, locations and functions exercised by centres ${ }^{7}$. The fact that shopping malls were built in the suburbs of cities and urban agglomerations or even away from them was caused by urbanisation processes and the formation of satellite systems around cities, as well as transport difficulties connected with getting to downtown centres, as the number of personal vehicles was rapidly increasing. This trend of the development of shopping centres of the first generation began at the first stage of their formation in the USA, in Western European countries and in Poland [Maleszyk 2000a, p. 27, Maryáš, Kunc, Tonev, Szczyrba 2014, pp.18-26, Karlsson 2012, p. 38]. The appearance of new settlement complexes, both within urban structures and in outer areas, resulted in favourable conditions for the creation of shopping centres of local and sub-regional character. Such type of shopping malls of second generation developed mainly in Western European countries within the framework of programmes for the modernisation of cities and urban agglomerations (Zipser 2004, pp. 117-126; Zipser 2006, Kunc, Tonev, Szczyrba, Frantál 2012, pp. 31-51).

In Poland, regional shopping malls are built principally in the largest urban agglomerations and in peripheral, external zones of metropolises (in outer metropolitan areas). Modern concepts related to urban planning, which provide for the separation of service functions in downtown centres in order to revitalise and stimulate them, constitute an inspiration to create a new, third generation of shopping centres with extended entertainment functions and professional services. A particularly interesting element contained in the designs of such shopping malls is the unique, original character of the offer of services of citywide and regional character.

\footnotetext{
${ }^{5}$ First facilities were of service and commercial character, but during their evolution next generations of malls have been developed (form the $1^{\text {st }}$ to the $5^{\text {th }}$ ). Further development stages (generations) of shopping malls are determined by their structural layout. Malls that combine trade with service activities belong to generation I, trade with service and entertainment activities - generation II, trade with service, entertainment and recreational activities - generation III, while malls combining trade and service, entertainment, recreational, cultural activities with residential and office offer represent generations IV and V.

${ }^{6}$ Example: entertainment, recreational, cultural activities and residential function.

${ }^{7}$ http://www.zw.com.pl, 03.05.2009
} 
Shopping centres of the latest generation are currently under intensive development. These multifunctional, integrated premises are becoming not only a shopping destination, but also a place in which it is possible to satisfy other needs: social and cultural needs, the need for entertainment, recreation, sport or relaxation. At another stage of development, the so-called facilities of fourth and fifth generation have been observed. They are distinguished by impressive architectural design, careful interior design, number of exercised functions, modern technological solutions and extensive marketing strategy that uses a wide range of means to attract the attention of consumers. There are also housing estates, hotels and offices built within them. They also provide specialist services, e.g. medical and consulting services, and even universities, churches, theatres or art galleries. A characteristic element of a new generation shopping mall is housing development situated in the immediate vicinity of the shopping centre. What is more, malls should have an appropriate structure. There has to be a kindergarten, a nursery or a specialist outpatient clinic $^{8}$. The aim of the project is to create a "city within a city".

In 2005, 184 modern shopping malls operated in Poland, while in 2013 there were already over 380 malls. At the end of the first half of 2013 , the total volume of shopping mall surface in Poland amounted to almost $8,973,400$ sq. m. of Gross Leasable Area (GLA). The surface of existing shopping centres amounts to 1.29 million sq. m. GLA in cities of up to 100,000 residents, 1.46 million sq. $m$. GLA in cities of $100,000-200,000$ residents, 1.05 million sq. m. GLA in cities of $200,000-400,000$ residents and 5.17 million sq. m. GLA in the largest agglomerations. Due to the growth rate of new retail space (ca. $15 \%$ a year), as of the 2008 (175 sq. m. per 1,000 inhabitants), the level similar to those observed in countries such as Germany, Austria or Switzerland has been achieved (Heffner, Twardzik 2013 p. 65-69).

The development of modern shopping malls in Poland takes place according to a scenario similar to the one observed in the Western Europe ${ }^{9}$.

\section{Shopping malls in Silesia Region}

Province of Silesia is inhabited by almost 4.7 million people, which constitutes $12.2 \%$ of the population of Poland, where 3.7 million are residents of cities. The region is placed on the first place in Poland when it comes to the level of urbanization $-78.4 \%$ of urban population.

Over the last ten years, in the province of Silesia, there has been a dynamic development of shopping centres. In 1998 - 2004 such complexes were being built mainly in the biggest cities of the Upper Silesian Conurbation. Main reasons of such a location are most of all having a good communications network and a huge market (about 2.5 million residents). In $2004-2007$ there was a shift of investors' interest when it came to the location of shopping centres. Investors were beginning to notice purchasing power and market possibilities of other regions of the province and directed their investments to towns with a number of residents raging between 100 - 200 thousand people. In subsequent years of 2008 - 2011 a process of the existing shopping centres' expansion into services, entertainment, sport, recreation, housing, office or hotel functions took place. New facilities, equipped with a diversified shopping-services offer have become a "substitute for public space" in many cities of the region, especially the ones located in city centres (Heffner, Twardzik 2013, p. 121).

\footnotetext{
${ }^{8}$ In Poland, until the end of the year 2000, the law allowed for an unrestricted inflow of foreign capital into the retail sector. In the years 2001-2007, an act which introduced the control over the shopping centre location exercised by city councils was in force. The control referred to the impact of investments on the local market, transport, existing retail chain and satisfying the needs and interests of consumers.

9 The analysis of available materials regulating the functioning and development of large-area facilities in Europe allows to state that a characteristic feature of regulations is a certain "socialisation" of decisions undertaken by local or central authorities.
} 
In 2013 there were 54 shopping centres ${ }^{10}$ in the province of Silesia operating in 18 cities, with the total surface area of $1,324 \mathrm{~m}^{2}$. In comparison with 2001 when in the province of Silesia there were 25 shopping centres with the total surface area of $533.5 \mathrm{~m}^{2}$ their number has increased by over $100 \%$ and retail surface area by $130 \%$. In each sub-region of the province, usually in the biggest settlement centres, there are modern shopping centres, both in city centres and in the outskirts. The present number of shopping centres in the province of Silesia constitutes $1 / 5$ of all shopping centres situated on the area of Poland, and their total surface area constitutes $21.5 \%$ of their entire surface area. In the initial period shopping centres development dynamics in the province of Silesia was the highest in Poland, in 1999 there were $33 \mathrm{~m}^{2}$ of commercial area per one thousand of residents (country's average $31 \mathrm{~m}^{2}$ ), whereas in 2005 a triple increase of the rate was noted to the level of $94 \mathrm{~m}^{2}$. Presently, the surface area of shopping centres in the province of Silesia is $382 \mathrm{~m}^{2}$ per 1,000 residents.

Shopping centres located in big and medium-size cities of the province of Silesia serve clients from the area of up to $120 \mathrm{~km}$ from their place of residence, which proves their over-regional influence. Taking into account their number, offer and location it can be assumed that they have a significant influence on the development and functioning of small towns and rural areas in the outer metropolitan zones.

\section{Rural areas in outer metropolitan zone in Silesia Region}

As far as the spatial and socio-cultural structure of European countries is concerned, small towns and their rural hinterland constitute an important element of the landscape, economy and social life. After the entrance of Poland into the European structures the ways of management and directions of socio-economic links between rural areas are subject to change, it impacts also the development conditions of small towns. Little urban centres functioning in metropolitan areas, in which economic, social and cultural changes take place in an extraordinarily dynamic way, are in particular situation in terms of development (Knox, Meyer 2011, pp. 142-158).

Small towns ${ }^{11}$ and their rural hinterland are home to a significant part of European countries' population, especially in regions in which agriculture still plays an important role. The original role of small towns in the settlement system came down to the function of local support of surrounding rural areas, while a large part of their inhabitants earned their living from agriculture. As far as the development of small towns is concerned, the functional type of the rural hinterland is of key importance. From this perspective, it is possible to distinguish three main types of rural surroundings of towns:

- agricultural (of dominant agricultural function and agricultural services);

- tourism-oriented (of a significant share of tourist function in the local economy);

- urbanised, often also industrialised, within the scope of influence of a large urban agglomeration (of dominant non-agricultural functions and a high level of urbanisation of villages, ex. rural areas in outer metropolitan zone in Silesia Region).

Due to the industrialisation of the $19^{\text {th }}$ and the $20^{\text {th }}$ century, in the scope of influence of large urban centres and their emerging agglomerations, rural areas entered into the phase of an impetuous urbanisation, suburbanisation and semi-urbanisation, which resulted in their profound functional transformation (Heffner 2000, pp. 103-118; Heffner 2000a, pp. 44-59).

Small towns located in spheres of strong influence of urban agglomerations are also subject to significant changes in municipal functions, which result mainly in an increasing role of

\footnotetext{
${ }^{10}$ In Poland, shopping malls appeared in the mid-1990s due to the investments of European retail chains. Their classification is based primarily on the number of stores in a shopping centre and divides them into three types: hypermarket with a small mall (20-60 shops), hypermarket with a large mall (over 60 shops), group of shops without a hypermarket. The main role in the market is played by large retail chains of transnational scope and strategy for action, such as Carrefour, Leclerc, Rewe, Obi, Metro AG, Jeronimo Martins, Leroy Merlin, Intermarche, Casino Group, Castorama and Tesco.

${ }^{11}$ In most studies, small towns are urban settlements with a population not higher than 20 thousand inhabitants within the administrative borders of a given town. See (Heffner 2005, p. 11-34).
} 
the residential function related with the fact that the majority of their residents capable of work have been absorbed by external labour markets - in large urban and industrial centres.

Analogous transformations constitute a characteristic feature of the rural hinterland of small towns. They change current patterns of service and strengthen shifts of at least a part of central functions to main urban centres. In urbanised areas, towns and their rural surroundings resemble more and more the outlying residential areas located within urban agglomerations. However, most of them maintain - primarily due to the existing morphological systems of local malls - basic service functions (Heffner, Marszał 2006, pp. 7-20).

Socio-economic processes, which were taking place in the second half of the $20^{\text {th }}$ century throughout Europe, significantly changed the external conditions for the development of small towns, also in Poland and in Silesia Region. Spheres of economic connections and of the influence of all large urban areas, in particular of metropolitan ones, expanded. Service functions of extended range (specialist and basic), locating in mass in their external areas, caused another change of the conditions for the development of small towns. Local centres, located within the scope of links with the central labour market and regional market, have been gradually transferring their remaining service functions (often only basic ones) to new shopping and service centres located on the outskirts of urban agglomerations (van Heur 2010, pp. 189192).

There is considerable evidence to indicate that small local centres located on the outskirts of agglomerations usually go through the process of transformation of municipal functions, which takes place under the influence of both central areas (cities of agglomerations) and in numerous new centres emerging in outer areas (shopping and service centres). Moreover, in the case of small local centres, traditional central functions (local shopping and service centres for neighbouring rural areas and mining districts) are transformed into mono-functional structures, in particular related to the rapid development of the residential function (in small towns as well as in their rural surroundings). In small towns located in the contact area with the remaining part of the region narrowly specialised services of basic character as well as the recreational and tourist functions can often be observed.

In the case of small local centres (small towns, rural communes), functional changes lead to spatial transformations which necessitate new forms of local development management, including utilities provision. At least some of relationships between the functioning of the local economy and economic behaviours of inhabitants in the zones of links between towns are not known to local politicians and activists engaged in their economic and social development. Economic behaviours of residents of cities and their rural surroundings are also recognised in a very superficial way (Heffner 2009, pp. 59-74).

Over a couple of decades preceding the year 2010, fundamental changes in the functional structure had taken place in urban centres in Poland. The process of deindustrialization, understood as a decline in employment in manufacturing and an increase in the importance of the service function, has become omnipresent. The phenomenon has become apparent in all urban centres, including small towns. Although in numerous little urban centres there still are small industrial plants, the significance of the industrial function has been decreasing due to a fast increase in the number of service and commercial establishments. As for the direction of the development of small centres (small towns), the functional type of the rural hinterland is of key importance. Such a dependence is confirmed by functional changes which take place in local centres located in the outer metropolitan area. In the vast majority of cases, the nodal location in the local space (i.e. the availability of the rural, but highly urbanised surrounding), the urban landscape and the "centrality" understood from the functional perspective - constitute the basic indicators and re-activators of the urban character of small towns in the zones of progressive suburbanisation. The spatial layout of centres of such type is a result of a historically shaped set of layers in the morphological system and buildings, as well as of the evolution of municipal functions.

In the light of new socio-economic conditions which occurred after 1990, attempts were made in many small urban centres to strategically redefine the role and the place of those centres in shaped spatial structures of metropolises and their rural surroundings - in particular in 
the expanding suburbanisation zones located around urban agglomerations. In small towns, attempts are made to find new boosts to development and to identify chances for the improvement of living conditions of local communities. Taking into account the competition for growth factors (residents, capitals, demand potential, renown of the place, etc.) with central areas of urban agglomeration, actions and activities focused on the use of the specific character of places, local advantages and opportunities probably constitute the best development strategy.

The objective of such actions should not be to develop this category of towns in the quantitative aspect, but rather to increase the quality of life and the attractiveness of small centres by means of the improvement of living conditions, growth of wealth of their inhabitants and enhancement of the marketing position.

The majority of towns fit in the economy of rural areas, but their significance for the country is subject - if the relationships are not sustained and developed - to fast degradation. In areas of metropolitan type, their economic links with the rural surroundings disappear or decrease to a large extent due to the existence of new forms of service and availability for rural residents, such as shopping malls, wholesale centres, centres of tourist services, etc.

Little urban centres located beyond the territory of large agglomerations usually arrange the rural space and are particularly predestined to play the role of local development centres. Among features which constitute the starting point for their integration with rural hinterland leading to the emergence of structures such as local economic areas, the most important include the multifunctionality, quality of urban area, economic efficiency of local structures, spatial availability and openness of the urban layout. At least some of relationships between the functioning of the local economy and economic behaviour of inhabitants in the zones of links between small towns are not known to local politicians and activists engaged in their economic and social development. Economic behaviour of residents of cities and their rural surroundings is also recognised in a very superficial way.

Main problems, which appear in the form of threats to the transformation process of rural areas related to towns, include principally: economic stagnation of small towns in outer areas of urban agglomerations, which is often connected with the industrial monofunctionality, negative demographic processes and phenomena of depopulation in the rural settlement network located on the outskirts of urban agglomerations, which limit the potential of local markets in small towns and increase in unemployment and lack of qualitative changes in the rural labour market, as well as related social threats.

It is possible to say that two general statements relate to the development of small urban centres and rural areas in the outer metropolitan area:

- development goals have to ensure the achievement of competitive advantages in possibly the widest rural hinterland (in this case, urbanised or partially urbanised one - in the suburbanisation zone),

- it is necessary to strive for possibly the largest share in the benefits of the influence in more distant (rural) zones.

The knowledge of the scale and scope of connections with the regional, national or international system makes it possible to assess the dependence of the local market of small towns and rural areas on the external economy. The factor determining the development of towns and the size of the area of service is the attractiveness of their resources and the scope of services provided in a given town. It is therefore recommended for regional policy to support actions significantly increasing the attractiveness of resources of small towns (it can be housing stock, service institutions, sets of monuments, recreational and tourist advantages, investment areas, etc.) (Leibovitz 2006, pp. 45-48).

For modern metropolitan areas and towns and rural areas located in their outer zones, it is also important to create good image of resident- and investor-friendly places, e.g. thanks to actions favouring the renewal of the urban fabric by means of revitalisation of degraded areas (e.g. areas previously in military, agricultural [large-scale] or industrial use, etc.). In this way, small 
urban centres in outer areas of urban agglomerations can compete in a more effective way for inhabitants who move from central areas to rural zones undergoing the urbanisation process. It is also necessary to undertake initiatives related to the development of space in centres of small towns and rural areas. Space with distinctive buildings (e.g. objects of historical value, cultural value), as well as appropriately developed places (green areas, areas valuable for cultural or natural reasons) should be recognised and preserved. All these actions and initiatives favour the development of attractive administrative and business, economic and recreational zones restoring at least some of traditional central functions of towns. The support should be focused mainly on actions increasing the attractiveness of their structural features (availability, quality of space, quality of the environment, central functions, image). The reason for it is that shopping and service centres built on the outskirts of agglomerations are becoming new competitors of towns, as they provide a comprehensive offer, high quality of services, convenient access and free parking.

Agriculture and rural areas in the Silesian Voivodeship are an important element of the regional economy. The arable land constitutes $39.2 \%$ of the total area of the voivodeship. There are approx. 102.1 thousand of farms operating on nearly 483.1 thousand ha. More than $82 \%$ of them are small farms with an area not exceeding 5 ha. Within the rural areas of the Silesian Voivodeship, there are 994.8 thousand people, which constitutes approx. $21.1 \%$ of the general population of the region, however a positive migration balance to rural areas has been observed for a couple of years. City inhabitants willingly move into suburban and rural areas, situated usually in the closest surroundings of a metropolis, seeking for better life conditions, peace, and convenience. Although they live outside town, most of their activity takes place there, e.g. work, shopping, entertainment, and in result, the place of residence becomes only their "sleepingroom", and the areas of small cities and villages - a monofunctional-residential place.

\section{Changes on the medium, small towns and rural areas in outer metropolitan zone in the Silesian Voivodeship}

The situation of small towns and rural communes located near metropolitan areas can be assessed in two ways. Large shopping malls and stores located in cities of an agglomeration may attract buyers from smaller localities. It will result in a disappearance of traditional forms of trade in small towns and rural communes. An appropriate policy regarding the provision of investment areas may result in shopping malls being located in smaller localities. In the case of studies of such type, it has to be clearly defined who is the beneficiary of particular activities undertaken by local authorities and who bears the costs of their decisions. Potential beneficiaries include, firstly, shopping malls and chains of stores - mainly groceries, and secondly, inhabitants who benefit from a more developed commercial offer. At the same time, the development of new forms of trade constitutes a threat to the existence of shops which have been functioning in particular small towns and rural areas to date.

The study was conducted in 14 communes of the Silesian Voivodeship. Medium-sized towns were: Pszczyna, Wodzisław Śląski, Myszków and Żywiec, towns were represented by: Kłobuck, Orzesze, Koziegłowy, Toszek and Imielin. As for rural communes, these were: Gorzyce, Suszec, Chełm Śląski, Ornontowice and Ślemień.

The attempt to identify factors which have the impact on the development of the retail use in the analysed communes of the Silesian Voivodeship constituting the outer metropolitan area was founded mainly on the definition of contemporary consumer behaviour penetrating into rural communes and small towns. Changes in attitudes related to the demand have a considerable influence on the transformation of the structure of trade and services. The aim of the study was to determine which forms of trade and services are developing, which of them are disappearing, and what is the cause of such a state of affairs. Evolutionary changes in the retail use aimed towards the development of shopping malls constituted a pretext to pose the question regarding positive and negative boosts to the development connected with this form of trade. Addressing such a question to the representatives of local authorities was justified, as it constituted the starting point for the discussion regarding the objectives of local policy related to 
the development of the retail use in communed of the outer metropolitan area. Among opinions on the trends in the development of trade, two points of view were mentioned most frequently.

First of all, in the structure of trade remained mainly small shops which were able to offer the assortment other than the one available in shopping malls and small chain supermarkets ( $71 \%$ answers among all respondents). The answers indicate that these small shops are usually family businesses with a strong market position from many years or offer specialised goods, often combined with counselling services, e.g. shops for fishermen, pigeon fanciers, etc. Second of all, over a half $(57 \%)$ of utterances mentioned a very visible expansion of small supermarkets, offering mainly a diversified food products. These shops often win the competition with local retailers by offering a wider range of goods and, at the same time, encouraging to shop by means of lower prices. The above mentioned chain stores make comprehensive grocery shopping possible and, thus, contribute to reduce the time spent in the shopping centre. An important feature of this type of facilities is the fact that they are selfservice stores which, according to the respondents, constitute a standard solution nowadays. That is why family shops which transformed into self-service facilities compete more effectively with chains of discount stores.

A comparison of answers given by representatives of rural communes and urban communes show that in the case of rural communes, the structure and form of trade have not undergone considerable transformations. Small shops offering food and manufactured goods are dominant, and trade activity is conducted by family businesses. In rural communes, consumer behaviour is traditional, i.e. most people buy food products in local stores located near their place of residence. However, it is possible to observe differences between older inhabitants, attitudes of whom does not change much, and young inhabitants who more and more often use the offer of shopping malls located in large cities. As for the majority of small, medium-sized towns and rural areas, which were the subject of the study, small chain supermarkets developed in the most intensive manner. In some of the towns, supermarkets were created where marketplaces used to function in the past.

In the case of a couple of localities, a significant role is still played by a fair (Orzesze, Żywiec, Kłobuck, Gorzyce - in total $27 \%$ of answers) It is often highlighted that in such a place not only food products, clothes and household appliances can be bought, but also livestock is sold (Żywiec). In few cases, a part of the traditional marketplace was used to build a supermarket. According to respondents, it is possible to observe inhabitants - especially at the end of the week - going shopping to large shopping malls located in the neighbourhood. For example, in Orzesze, Chełm Śląski and Ślemień, private transporters offer additional buses that transport customers to shopping malls.

Another trend observed in the analysed localities is the disappearance of door-to-door selling (not so long ago many people bought food products in such a way in Suszec) and of street trading, which are considered to be very provisional solutions which lose the competition with self-service stores. The survey also indicated a decline of shops and services which were omnipresent in the past and which lost their significance due to the development of the civilisation. That is how shops offering e.g. articles for blacksmith disappeared (e.g. in Ślemień). Chain general stores located in towns make it possible to plan the amount of time spent on shopping in a more flexible way. The respondents indicated e.g. that such stores offered more convenient opening hours than small shops. Supermarket chains are opened seven days a week, from early morning to late evening.

All things considered, it has to be stated that the main factor determining changes in the retail sector are variable preferences of customers who appreciate especially comfortable shopping and a wide range of products and services. Local retailers who want to effectively compete with supermarkets are forced to improve the standard of service or to find market niches by offering specialist products and services. The trends in consumer behaviour discussed above and related to the development of shopping malls may generate, in the opinion of the representatives of local authorities, both positive and negative boosts to the development of a commune. 
It has to be said that the respondents emphasised more the existence of positive boosts. In particular in places which interviews were conducted, it was indicated that the development of shopping centres and malls was inevitable. Therefore, the authorities encourage locating such facilities in the territory of their commune, as otherwise such premises would be created anyway in a neighbouring city. Among positive boosts to the development related to the construction of shopping malls the respondents enumerated the creation of new jobs in both retail and service sectors (57\% of answers). It has to be added that in the most cases jobs were created outside the analysed communes, as shopping malls were built in large cities and that is where the inhabitants of smaller localities were hired.

In the case of the development of commercial facilities in the territory of the analysed communes, respondents mentioned also advantages in the form of increased budget revenue in the form of rent for lease and property tax (e.g. Imielin, Chełm Śląski, Orzesze, Pszczyna, Wodzisław Śląski, Żywiec). It was also stated that an investor using an area for commercial activity operates effectively, achieves return on invested capital in a short period of time and, thus, is a low-risk, i.e. desired, business entity for the commune (Polko 2013).

It was often stated that shopping malls which had been created in medium-sized towns and small local centres aspired to be an important place on city maps. The most important aspect mentioned was of course the higher comfort of shopping and a possibility to save time. The element of time appeared also in another context, i.e. in relation to opportunities connected with spending leisure time. Restaurants, cafés and other catering establishments, which are often located in malls of even small shopping centres, become a place of traditional meetings. In bigger centres or malls, a multiplex or a bowling alley often offer a couple of hours of fun for entire families (Hubbard 2003).

In the case of localities with sightseeing and recreational qualities, the construction of shopping malls was justified, as it was related to a considerable turnover generated by tourists as well as by households having so-called secondary residences in the vicinity (Heffner, Czarnecki 2011). For example, persons residing in Żywiec and Ślemień during holidays or weekends used to bring many products with them. Today, they shop on the spot, benefiting from a diversified offer of shopping malls and smaller grocery chains.

In the course of the interviews, opinions were presented according to which the development, especially of modern forms of trade, generates positive effects in the form of the improvement of the commune's image and of the quality of transport system, as the construction of facilities is often accompanied by a reconstruction of approach roads, which is beneficial for the customers of shops and for local residents.

In addition to the above mentioned positive boosts, the respondents were asked to indicate negative factors related to the construction of shopping malls. The most common answers $(64 \%$ of respondents) referred to the outflow of customers from small shops and, as a result, their liquidation. In most analysed places, small shops which have not adapted to modern consumer needs lose the competition with shopping malls and supermarket chains. The comparison of answers concerning positive and negative boosts to the development related to the location of shopping malls in their territory or in the neighbourhood shows an ambivalent attitude of the respondents, in particular as far as the number of jobs is concerned, as new jobs are created thanks to the construction of shopping malls, but at the same time people lose their jobs due to the liquidation of some of the small shops. Nevertheless, what is important is that in $36 \%$ of cases the respondents did not see any negative development trends related to the development of new forms of trade. The lack of negative opinions was noted mainly in the following rural communes: Suszec, Ornontowice, Ślemień. Residents from these communes said that consumer behaviour, as well the structure of trade, had not changed significantly. In these communes, shopping malls were not created, so they do not compete with local retailers. It was stated that their residents can benefit from shopping centres located in large cities, as their offer is complementary and includes mainly products and services which are unavailable in rural communes and small towns (fig.1). 


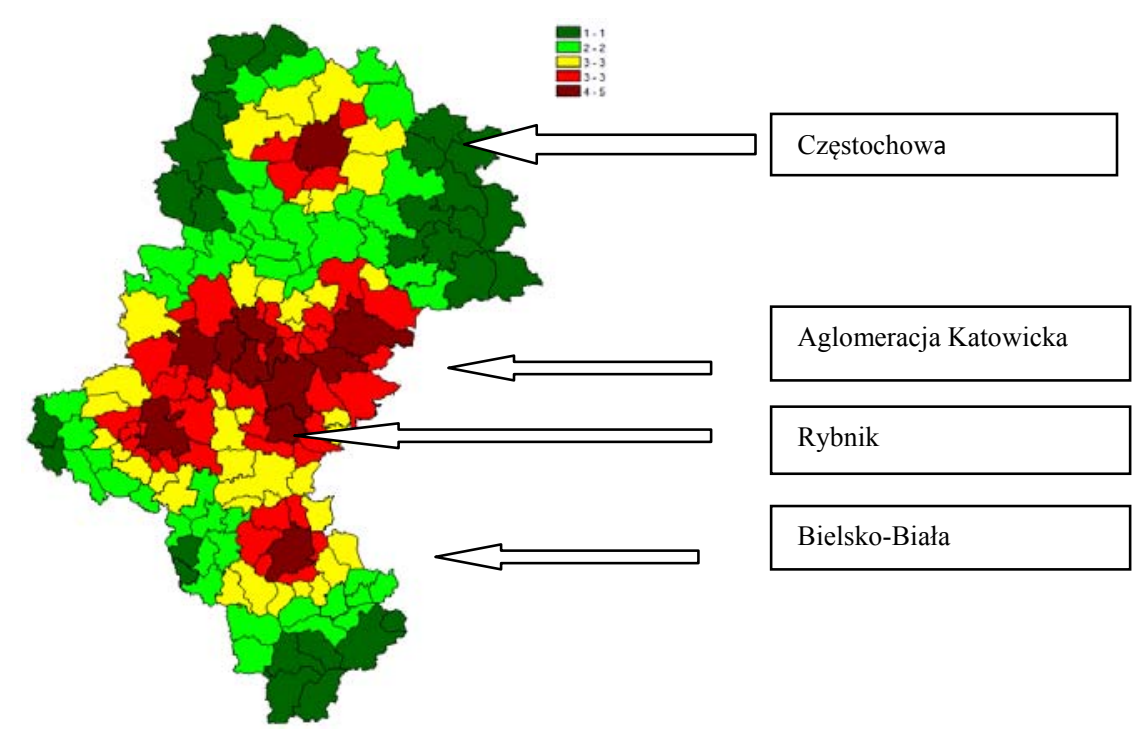

Fig 1. Delimitation of metropolitan areas of the Silesian Voivodeship and the scope of their impact. Source: Own study.

Changes in consumer behaviour penetrating into communes influenced by large urban agglomerations constitute the result of local policy regarding the development of the retail use in towns and rural communes. The comparison of investment offers of the analysed communes allows to notice relationships between the size of communes and their location. In the case of rural communes, the directions of the development are determined mainly by natural assets. Communes having a potential in the form of mountains, lakes and forests concentrate on the development of the tourist function and investors from this sector are the most desired (e.g. Ślemień). In other rural communes, such as Chełm Śląski, Suszec or Ornontowice, good transport connections with towns of the Upper Silesian Agglomeration and, thus, an opportunity for the development of residential areas were highlighted. Most of the areas offered by communes are designated for single-family housing characterised by low-intensity development. In the case of such communes, the development priority is to improve the quality of life and the attractiveness as a residential area. Investments of such communes are focused on the educational and sports infrastructure, as well as on the creation of places to spend leisure time.

In the case of urban communes (medium-sized and small towns) often located in the immediate vicinity of the Upper Silesian Agglomeration, the offer of investment areas is addressed to both investors from the housing sector and companies manufacturing goods. In current spatial development plans, the land for the construction of large-area commercial facilities is often located next to major routes (e.g. in Orzesze, near to the road towards Gliwice), while in city centres it is possible to use areas for the purposes of small commerce and services. In most of the analysed medium-sized towns, the research on conditions and trends related to spatial planning included the possibility to locate commercial facilities the sales area of which exceeded $2,000 \mathrm{~m}^{2}$. In Wodzisław Śląski, such premises can be built next to the bus station, near the city stadium, in Żywiec large-area commercial facilities can be created in former manufacturing plants and market hall in the city centre. In the case of most communes it is difficult to determine any activities aimed at supporting the sector of trade and services.

Usually, the communes do not use any instruments protecting local retailers. It was stated that one shopping mall would contribute to the creation of a larger number of jobs and higher budget revenues than a couple of small shops.

The last questions concerned the opinion regarding opportunities and threats related to the fact being located in the vicinity to large cities of the Upper Silesian Agglomeration. The majority of answers indicated that the proximity of larger cities had positive effects. The closer a given commune was located in relation to the agglomeration, the more positive impact was stated. Persons representing communes located far from urban agglomerations did not mention opportunities nor threats connected to a limited, in their case, availability of metropolitan areas. 
As far as positive factors are concerned, respondents highlighted mainly benefits such as the commercial and cultural offer, as well as specialist medical services located in Katowice, Gliwice and other cities of the Upper Silesian Agglomeration. The proximity of a metropolitan area increases the chance for attracting investors to a given town. It has a positive effect on the situation in the labour market and ensures higher local budget revenues. Authorities of towns and communes consider that the process of suburbanisation and of the "spillage" of cities also provide opportunities. They hope that some agglomeration residents will want to move to more attractive residential areas, created and offered in the territory of towns located around the Upper Silesian Agglomeration (this fact was accentuated e.g. in Suszec, Chełm Śląski, Orzesze, Ornontowice). What is more, $35 \%$ of responders does not perceive any threats related to the proximity of a large urban agglomeration.

\section{Conclusions}

Surveys make it possible to formulate some general conclusions regarding the impact of shopping malls on the functional and spatial structure of the above mentioned communes.

Firstly, in the territory of small towns and rural communes, progressive and diversified transformations of the structure of trade can be observed, as a result of changes in the consumer behaviour. The intensity of modifications depends on the size of a given commune and its proximity to a metropolitan area. In rural communes, functional and spatial transformations related to the retail sector take place at a slower pace (much more considerable changes concern residential areas), while in small and medium-sized towns they result mainly from the expansion of grocery supermarket chains. Despite of restrictions in terms of the diffusion of consumer behaviour trends from metropolises to their outer areas, transformations seem to be inevitable. Modern commerce techniques, such as online sales and group purchases, eliminate barriers associated with distance or economies of scale and make it possible also for residents of the outer metropolitan area to participate in the entire commercial and service offer.

Secondly, there are more positive aspects connected with the development of the retail use than those which may have a negative impact. It is thought that the location of shopping malls and supermarkets is beneficial both for the commune (revenues from local taxes and charges, new jobs) and for individual customers (more comfortable shopping, wider range of products, possibility to enjoy ways of spending leisure time, which were not available before). Negative changes, consisting mainly in the liquidation of small shops, are considered to be a natural consequence of market gambling.

Thirdly, the sector of trade and services is, from the point of view of local authorities, the main factor in the development. While trying to attract external investors, local governments focused mainly on manufacturing companies (small and medium-sized towns) or on entrepreneurs form the sector of tourism and recreation, as well as on housing investors (rural communes). As a consequence, there are also no instruments aimed at protecting local retailers.

Fourthly, according to the representatives of local authorities, the proximity of a metropolis generates more positive than negative developmental effects. The location in an outer metropolitan area is treated as an opportunity thanks to, above all, the availability of urban facilities (e.g. specialist medical services, higher education, culture) and labour market, which contribute to the improvement of the quality of life of people living in rural communes and small towns. Moreover, another opportunity is the possibility to bring in new residents thanks to an attractive offer in terms of single-family housing.

At the stage of the irrepressible process of suburbanisation of rural areas surrounding large urban agglomerations and structural changes in towns, it is difficult to conclusively assess the consequences of the operation of shopping malls in outer economic areas in the Silesian Voivodeship. Opinions of residents are positive and indicate many benefits, while the point of view of entrepreneurs is rather negative, as they mention many threats and barriers to the development of business activity. The position of local authorities depends on the location in relation to a large urban centre and the intensity of interconnections. The impact of shopping 
malls on small towns and rural areas located in the outer economic area is, in terms of time and form, a dynamic process which requires further systematic research.

\section{References}

[1] Amcoff, J., Moller, P. \& Westholm, E. (2011). The (un)importance of the Closure of Village Shops to Rural Migration Patterns. The International Review of Retail, Distribution and Consumer Research, 21(2), 129-147. Doi: 10.1080/09593969.2011.562678.

[2] Heffner, K. (2000). Problemy sieci osadniczej a kształtowanie się lokalnych centrów rozwoju. In Kłodziński, M. \& Rosner, A., eds., Rozwój przedsiębiorczości na terenach wiejskich wschodniego $i$ zachodniego pogranicza (społeczne, ekonomiczne i instytucjonalne uwarunkowania), Warszawa, Instytut Rozwoju Wsi i Rolnictwa PAN.

[3] Heffner, K. (2000). Kreacja ośrodków wielofunkcyjnego rozwoju na obszarach wiejskich. Wieś i Rolnictwo 107(2), 43.

[4] Heffner, K. \& Marszał, T. (2006). Uwarunkowania rozwoju i zmiany w zagospodarowaniu małych miast w Polsce w drugiej połowie XX w. In Heffner, K. \& Marszal, T., eds., Uwarunkowania rozwoju małych miast. Warszawa, Committee of Spatial Economy and Regional Planning.

[5] Heffner, K. (2009). Rola małych miast w rozwoju obszarów wiejskich - porównania europejskie, In Poczobut, J., ed., Specyfika odnowy małych i średnich miast w Polsce. Kraków: Stowarzyszenie Forum Rewitalizacji.

[6] Heffner, K., Czarnecki, A., eds. (2011). Drugie domy w rozwoju obszarów wiejskich. Warszawa: Institute of Rural and Agricultural Development PAN.

[7] Heffner, K. \& Twardzik, M. (2013). The impact of shopping malls on the outer metropolitan zones (the example of the Silesian Voivodship), Studia Regionalia 37, Warszawa: Committee of Spatial Economy and Regional Planning.

[8] van Heur, B. (2010). Small cities and the geographical bias of creative industries research and policy, Journal of Policy Research in Tourism, Leisure and Events, 2 (2), 189-192. Doi: 10.1080/19407963.2010.482281.

[9] Hubbard, P. (2003). A good night out? Multiplex cinemas as sites of embodied leisure. Leisure Studies 22(3), 255-272. Doi: 10.1080/026143603200075461.

[10] Karlsson, E. B. (2012): Retail in Rural Regions. Exploring ways to support rural shops. Bifrost: Center for Retail Studies.

[11] Knox, P. L. \& Meyer, H. (2011). Europe's Internal Periphery. Small Towns in the Context of Reflexive Polycentrity (pp. 142-157). In van Heur, B. \& Lorentzen, A., eds., The Cultural Political Economy of Small Cities. London: Routledge.

[12] Kunc, J., Tonev, P., Szczyrba, Z. \& Frantál, B. (2012): Commuting for Retail Shopping as a Part of the Daily Urban System (Brno, the Czech Republic). Geographia Technica, 7(1), 36-45.

[13] Leibovitz, J. (2006). Jumping Scale: From Small Town Politics to a 'Regional Presence'? Re-Doing Economic Governance in Canada's Technology Triangle (pp. 45-58). In Bell, D. \& Jayne, M., eds., Small Cities: Urban Experience Beyond the Metropolis. London: Routledge.

[14] Leeuwen, E. S. van \& Rietveld, P. (2011). Spatial Consumer Behaviour in Small and

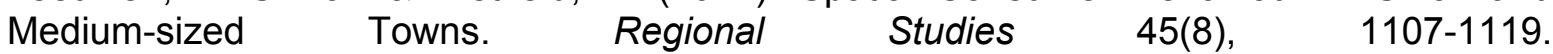
Doi: $10.1080 / 00343401003713407$.

[15] Lukić, A. \& Jakovčić, M. (2004). Location and Functions of Hypermarkets and Shopping Centres in Zagreb. Dela, 22, 39-54. 
[16] Maleszyk, E. (2000). Ośrodki handlowe w Polsce-uwarunkowania, kierunki rozwoju. Warszawa: Instytut Badań Rynku, Konsumpcji i Koniunktur.

[17] Maryáš, J., Kunc, J., Tonev, P. \& Szczyrba, Z. (2014). Shopping and services related travel in the hinterland of Brno: Changes from the socialist period to the present, Moravian Geographical Reports 22(3), 18-28. Doi: 10.2478/mgr-2014-0015.

[18] Twardzik, M. (2013). Impact of shopping malls on the outer metropolitan area and their social influence (pp. 85-102). In Heffner, K. \& Twardzik, M, eds., The impact of shopping malls on the outer metropolitan zones (the example of the Silesian Voivodship), Studia Regionalia 37, Warszawa: Committee of Spatial Economy and Regional Planning.

[19] Polko, A. (2013). Impact of shopping malls on the functional and spatial structure of communes in the outer economic area (pp. 127-140). In Heffner, K. \& Twardzik, M, eds., The impact of shopping malls on the outer metropolitan zones (the example of the Silesian Voivodship), Studia Regionalia 37, Warszawa: Committee of Spatial Economy and Regional Planning.

[20] Powe, N. A. \& Shaw, T. (2004). Exploring the current and future role of market towns in servicing their hinterlands: a case study of Alnwick in the North East of England. Journal of Rural Studies, 20(4), 405-418. Doi: 10.1016/j.jrurstud.2004.07.003.

[21] Sić, M. (2007). Spatial and Functional Changes in Recent Urban Development of Zagreb. Dela 27, 5-15. Doi: 10.4312/dela.27.1.5-15.

[22] Zipser, W. (2004). Oddziaływanie wrocławskich hipermarketów na klientów - mieszkańców Dolnego Śląska (pp. 127-136). In Bagiński, E, ed., Wybrane wyniki badań nad miejską siecią osadniczą Dolnego Śląska. Wrocław: Oficyna Wydawnicza Politechniki Wrocławskiej.

[23] Zipser, W. (2006). Usługi wielkopowierzchniowe a zachowania przestrzenne mieszkańców dużych miast (na podstawie wrocławskich obserwacji) (pp. 63-80). In Klimek, R. \& Słodczyk, J., eds., Przemiany przestrzeni miast $i$ stref podmiejskich. Opole: Uniwersytet Opolski. 